\title{
DEVELOPMENT OF Tabebuia aurea AND Anadenanthera macrocarpa UNDER DIFFERENT LEVELS OF SHADING
}

Gleydson Vinicius dos Santos Silveira' ${ }^{(1 D}$, Alan Cauê de Holanda ${ }^{2}$, Allyson Rocha Alves ${ }^{3}$ (1) Françóyse Dávila de Souza Silva $^{4}$ (1) \& João Lucas Rebouças de Oliveira ${ }^{5}$ (iD)

1 - Forest Engineer Undergraduate Student, UFERSA/Mossoró-RN, gleydsonvinicius2013@gmail.com;

2 - Forest Engineer, Dr. Professor at UFERSA/Mossoró-RN, alan.holanda@ufersa.edu.br;

3 - Forest Engineer, Dr. Professor da UFERSA/Mossoró-RN, allyson@ufersa.edu.br;

4 - Forest Engineer Undergraduate Student, UFERSA/Mossoró-RN, francoysedavilla@gmail.com;

5 - Forest Engineer Undergraduate Student, UFERSA/Mossoró-RN, lucas.joaolucasreboucas.joo9@gmail.com

\section{Keywords:}

caatinga

luminosity

seedling quality

\section{ABSTRACT}

The efficiency in the initial growth of trees can be related to the ability of the seedlings in adapting to different light intensites in the enviroment. The objective of this work was to evaluate the influence of different levels of shading in the initial growth of Tabebuia aurea and Angico (Anadenanthera macrocarpa) in the nursery phase. The experiment was conducted at the Federal Rural University of Semiárido located in Mossoró-RN. The seeds of A. macrocarpa and T. aurea were collected from parent trees and donated by the Caatinga/UFERSA/ Petrobras Project, where, afterwards, they were processed. The composting used in the experiment was coconut fiber, after the substrate was placed in $55-\mathrm{cm}^{3}$ tubes and organized in plastic supports. The seedlings were submitted to three levels of shade, full sun (absence of shade), shade of $50 \%$ and $80 \%$. For the different levels of shading, mean values of the height/diameter ratio of the neck were obtained of 3.74 (A. macrocarpa) and 1.57 ( $T$. aurea) for cultivation in full sun, $0 \%$ of shading, indicating that the growth of this cropt may have better results under these conditions. The highest values of the Dickson Quality Index (DQI) were observed in seedlings grown under a lower shade level of 0.03454 and 0.11719 . The species $T$. aurea shows little tolerance when subjected to high levels of shading, showing that the luminosity interfere in the initial growth of the species. A. macrocarpa, also acquired a better development in full sun, showing less progress at higher levels of shading.

Palavras-chave:

qualidade de mudas luminosidade caatinga

\section{DESENVOLVIMENTO DO ANGICO-VERMELHO E CRAIBEIRA EM DIFERENTES NÍVEIS DE SOMBREAMENTO}

\section{RESUMO}

A eficiência no crescimento inicial de árvores pode ser relacionada á habilidade de adaptação das plântulas a distintas luminosidades do ambiente. Este trabalho objetivou avaliar a influência de diferentes níveis de sombreamento no desenvolvimento inicial da Craibeira (Tabebuia aurea) e Angico (Anadenanthera macrocarpa) na fase de viveiro. O experimento foi conduzido na Universidade Federal Rural do Semiárido localizado em Mossoró-RN. As sementes de A. macrocarpa e T. aurea, foram coletadas de árvores matrizes e doadas pelo Projeto Caatinga/ UFERSA/ Petrobras onde, após, foi feito o seu beneficiamento. O composto utilizado no experimento foi fibra de coco, em seguida foi colocado o substrato em tubetes de $55 \mathrm{~cm}^{3}$ e organizada em suportes plásticos. As mudas foram submetidas a três níveis de sombreamento, pleno sol (ausência do sombrite), sombrite de $50 \%$ e $80 \%$. Para os diferentes níveis de sombreamento obtiveram-se valores médios da relação altura/diâmetro do coleto de 3,74 (A. macrocarpa) e 1,57 (T. aurea) para o cultivo a pleno sol, $0 \%$ de sombreamento, indicando que o crescimento desta cultura pode ter melhor resultado nestas condições. Os maiores valores do Índice de Qualidade de Dickson (IQD) foram observados em mudas cultivadas sob menor nível de sombreamento 0,03454 e 0,11719. A espécie T. aurea apresentou-se pouco tolerante quando submetida a níveis elevados de sombreamento, indicando que a luminosidade interfere no crescimento inicial da espécie. A. macrocarpa, obteve, também, melhor desenvolvimento a pleno sol, apresentando menor progresso aos níveis mais altos de sombreamento. 


\section{INTRODUCTION}

Because light is the primary source of energy and related to photosynthesis (CAMPOS; UCHIDA, 2002) it is one of the major factors that influences the growth and development of plants (LIMA et al., 2008).

Artificial shading is a technique used to obtain gains from different environmental factors, especially light and its relationship with the harmful action of the sunlight, particularly in periods with high energy availability, as well as it contributes to reduce the temperature of plant.

The diversity of plant responses to light is great, especially regarding the growth and vegetative development of the aerial part and the survival of seedlings. In this way, the capacity for plant growth can be related to the ability to adaptation of the seedlings to the light conditions of the environment (SOUSA; JARDIM, 2007).

The concern with the impacts generated on the environment has intensified over the years, increasing the current demand for the production of seedlings of forest species, with the purpose of reforesting deforested areas. Some forest species can be used to recover degraded areas. Pioneer species, according to Chaves et al. (2006), when used in the regeneration of these areas, allow the subsequent establishment of other species, the stabilization and the increase of the soll biological activity.

Anadenanthera macrocarpa (Benth) Brenan (Angico) belongs, in the study of succession, to the group of the initial secondary ones, and its natural restructuring is considerable, succeeding basically through seeds, besides presenting several uses, among them the use of its wood for firewood production and in the recovery of degraded areas (CHAVES et al., 2006).

Another species chosen to compose the job was the Tabebuia aurea (Benth) Moore which is a tree species of the Bignoniaceae family, popularly known as Craibeira, it predominates on the banks of temporary rivers in the semiarid Northeast, besides being part of the flora of the Cerrados and Cerradões of almost all of Brazil (OLIVEIRA et al., 2006).

Due to its medium-texture wood, T. aurea has multiple uses, such as application in frameworks, frames, furniture, tool handles, civil construction, besides being applied in the afforestation of streets and squares due to its abundance of showy flowering and shade that it can provide. In addition, it presents rapid growth and can be indicated for reforestation, mainly in riparian forests, in regions with low rainfall (CABRAL et al., 2003).

Given this context and the social, economic and environmental importance that the respective species present for the semiarid region, the objective of this work was to evaluate the influence of different levels of shading in the initial development of Silver trumpet-tree and Angico in the nursery phase.

\section{MATERIAL AND METHODS}

The experiment was conducted at the Federal Rural University of Semiarido located in Mossoro, State of Rio Grande do Norte (RN). The climate of the region according to the classification of Köppen, is of the BSwh' type, that is, dry and very hot, with two climatic seasons: a dry season usually from June to January, and a rainy season, from February to May. The average annual precipitation is $695 \mathrm{~mm}$, the relative humidity is $70 \%$ and the average annual temperature is $27.4^{\circ} \mathrm{C}$ (COSTA et al., 2018).

The seeds of $A$. macrocarpa and T. aurea were collected from parent trees and donated by the Caatinga/UFERSA /Petrobras Project, where, afterwards, they were processed. The substrate for the trays were prepared by moistening coconut fiber, without using nutrients. Then, it was placed in $55-\mathrm{cm}^{3}$ tubes and organized in plastic trays. The trays were placed on suspended beds and irrigated daily during the morning. Two seeds per container were sown to ensure the germination of a seedling.

The seedlings were subjected to three levels of shade: full sun (absence of shade), 50\% and $80 \%$ shade. Each treatment contained 10 (ten) replicates. The experiment was maintained with manual irrigation once a day.

After germination and growth uniformization (14 days), thinning was carried out, leaving only those individuals which showed greater vigor. The diameter of the neck $\left(D_{\text {neck }}\right)$ and the height of the plants $(\mathrm{H})$ were evaluated weekly. At the end 
DEVELOPMENT OF Tabebuia aurea AND Anadenanthera macrocarpa UNDER DIFFERENT LEVELS...

of the experiment, at 44 days, the seedlings were removed from the tubes and placed in the oven at $105^{\circ} \mathrm{C}$, for 72 hours, and, after that, weighed on a precision scale, to obtain the weights of the dry matter of the aerial part (APDM), roots (RDM) and the APDM / RDM ratio.

The morphological parameters of the seedlings and their relations used in the evaluation of the results were the height of the aerial part $(\mathrm{H})$, diameter of the neck $\left(\mathrm{D}_{\text {neck }}\right)$, the relationship between the height of the aerial part and the diameter of the neck $(\mathrm{H} /$ $\mathrm{D}_{\text {neck }}$ ), the dry matter of the aerial part (APDM), root (RDM) variable, relationship between APDM and RDM, and Dickson's quality index (IQD), using the formula expressed by equation (1) (DICKSON et al., 1960).

Three measurements were made during an interval of 44 days and the design adopted in the experiment was the completely randomized, with two species, three treatments and 10 replicates in each treatment. The data were submitted to analysis of variance and the means compared by the test of Tukey at $5 \%$ probability $(\mathrm{p}>0.05)$.

$\mathrm{DQI}=\frac{\frac{\mathrm{TDMW}}{\mathrm{H}}}{\text { Dneck }}+\frac{\text { APDM }}{\text { RDM }}$

Where,

$\mathrm{DQI}=$ Dickson Quality index;

TDMW = total dry matter weight, g;

$\mathrm{H}=$ aerial part height, $\mathrm{cm}$;

$\mathrm{D}_{\text {neck }}=$ neck diameter, $\mathrm{mm}$;

APDM = aerial part dry matter weight, $g$; and

$\mathrm{RDM}=$ root dry matter weight, $\mathrm{g}$.

\section{RESULTS AND DISCUSSION}

Different responses were found at $5 \%$ probability in the growth in height $(\mathrm{H})$ among the treatment levels studied (Table 1). In both species, $\mathrm{H}$ growth was greater at the $80 \%$ level, with values of $7.16 \mathrm{~cm}$ for $T$. aurea and $6.36 \mathrm{~cm}$ for A. macrocarpa. In addition, in the latter species, the full sun (no-shade) showed the lowest growth among the three levels of shading, whereas in the species $T$. aurea, the $\mathrm{H}$ value was statistically equal to the $50 \%$ shading and full sun treatments.

A. macrocarpa showed no statistical difference for the neck diameter (Dneck) between the different levels of shading. For $T$. aurea, the neck diameter was greater in the development in full sun (2.29 $\mathrm{mm}$ ), and the lowest value of $1.36 \mathrm{~mm}$ for the $50 \%$ shade, however, not statistically different from the $80 \%$ shade (1.68).

The relationship between height and neck diameter $\left(\mathrm{H} / \mathrm{D}_{\text {neck }}\right)$ for A. macrocarpa was higher (6.68) in the $80 \%$ shading treatment, but not significantly different from the $50 \%$ level (5.68). In the $\mathrm{H} / \mathrm{D}_{\text {neck }}$, for T. aurea, a higher value was found for the $80 \%$ treatment (4.73), and a significantly lower value (1.57), for full sun.

The height, itself, analyzed alone is not an effective indicator of seedling quality. However, when associated with another parameter such as the diameter of the collection, it is possible to have greater precision in observing the seedling of greater development. As seen in Table 1, the $80 \%$ shade treatment provided greater growth in height, but this result may at first be linked to the fact that, due to the competition for light, the etiolation

Table 1. Means of height, neck diameter, and rate between height and neck diameter $\left(\mathrm{H} / \mathrm{D}_{\text {neck }}\right)$ of the species at different levels of shading

\begin{tabular}{ccccccc}
\hline & \multicolumn{3}{c}{ SPECIES } \\
\cline { 2 - 7 } SHADING & $\begin{array}{c}\text { Height } \\
(\mathrm{cm})\end{array}$ & $\begin{array}{c}\text { Diameter } \\
(\mathrm{mm})\end{array}$ & $\mathrm{H} / \mathrm{D}_{\text {neck }}$ & $\begin{array}{c}\text { Height } \\
(\mathrm{cm})\end{array}$ & $\begin{array}{c}\text { Diameter } \\
(\mathrm{mm})\end{array}$ & $\mathrm{H} / \mathrm{D}_{\text {neck }}$ \\
\hline & $3.71 \mathrm{c}$ & $1.03 \mathrm{a}$ & $3.74 \mathrm{~b}$ & $3.45 \mathrm{~b}$ & $2.29 \mathrm{a}$ & $1.57 \mathrm{~b}$ \\
\hline $\begin{array}{c}\text { Full sun (absence of } \\
\text { shade) }\end{array}$ & $4.71 \mathrm{~b}$ & $0.88 \mathrm{a}$ & $5.68 \mathrm{a}$ & $3.78 \mathrm{~b}$ & $1.36 \mathrm{~b}$ & $3.27 \mathrm{ab}$ \\
\hline $50 \%$ & $6.36 \mathrm{a}$ & $0.99 \mathrm{a}$ & $6.68 \mathrm{a}$ & $7.16 \mathrm{a}$ & $1.68 \mathrm{~b}$ & $4.73 \mathrm{a}$ \\
\hline $80 \%$ & &
\end{tabular}

*Means were analyzed for each species by the test of Tukey at $5 \%$ probability. 
occurred between individuals.

According to Larcher (2004), the high growth in the length of the aerial part occurs when the plant is submitted to light intensities below the necessary, investing in its stem elongation, however, without presenting biomass accumulation. For Eloy et al. (2013), the height of the aerial part has always been used efficiently to find an estimated value of the seedling quality standard.

It can be seen in the evaluation of the neck diameter that there was no statistical difference in the diameters between the shading levels for A. macrocarpa. However, for T. aurea there was this difference, in which the treatment that had the highest mean value for diameter was in full sun.

In comparison to the total height, neck diameter better expresses the quality of the seedling to be taken to the field in terms of survival and, theoretically, reveals a greater relationship in the accumulation of biomass between the aerial part and the root system. One explanation for this may be due to the cambial rate growth, which can occur in plants that receive greater sunshine (SARAIVA et al., 2014). Since, the growth of cambial cell is first influenced by the large consumption of carbohydrates resulting from photosynthesis, the cambial activity is highly dependent on light (WANGINIAK, 2016).

The increase in shading may decrease photosynthesis and the amount of photoassimilates and growth regulators, reducing the neck diameter (MARANA et al., 2015). It should be pointed out that the tolerance to light for a particular species is something intrinsic besides being related to adaptive and physiological aspects, and can vary between the various environmental conditions occurring in Brazil.

Unlike height, the neck diameter is, itself, a good indicator of seedling survival, since, in addition to survival, the diameter serves as an indicator of the evaluation of the species' rusticity (ROSA et al., 2009).

Through the $\mathrm{H} / \mathrm{D}_{\text {neck }}$ ratio, it is possible to select the seedlings that can be taken to the field. In this work, both species showed lower values in the treatment under full sun, which are the ideal to be taken to the field.

The low $\mathrm{H} / \mathrm{D}_{\text {neck }}$ values indicate balance in the development of the species, as stated by Caldeira et al. (2008) when they described that the height of the aerial part combined with the neck diameter constitutes one of the most important morphological parameters to estimate the growth of the seedlings after definitive planting in the field.

The $\mathrm{H} / \mathrm{D}_{\text {neck }}$ ratio is one of the non-destructive, morphological methods, which reveals the quality of a seedling to be taken for planting in the field that has a direct impact on its survival (NÓBREGA et al., 2007). Thus, as observed, for both species, seedlings produced in full sun showed better qualities when compared to other treatments.

A similar result was found by Câmara and Endres (2008), for the species Mimosa caesalpiniifolia and Sterculia foetida whose $\mathrm{H} / \mathrm{D}_{\text {neck }}$ ratio presented the highest means under $70 \%$ of shading and the lowest means when submitted to treatment in full sun, for this rate. According to Vieira et al. (2014), the $H / D_{\text {neck }}$ ratio is one of the most accurate indexes to inform how thin the seedling is and its ability to establish in the field after planting.

Regarding the dry mass of the root system and aerial part (Table 2), the species $T$. aurea showed better development when submitted to conditions of high luminosity. The APDM/ RDM ratio decreased as luminosity increased, with a lower value of 1.11 at full sun, however, there is no significant difference with the other levels of shading (Table 2). Very high values for the APDM/ RDM ratio can be negative for the seedlings, as it indicates a tendency of growth imbalance, with consequent damping of the seedlings, and possible problems with regard to water absorption for the aerial part (GOMES et al., 2013).

A. macrocarpa obtained an APDM / RDM ratio of 0.64 in full sun, which comprises a more homogeneous development between the aerial part and the root, with the lowest value between the different levels of shading, which demonstrates a balance in the growth of the seedlings. The development of root dry mass in full sun for $T$. aurea with 0.15 (g) stands out, and the lowest value found was in the $80 \%$ shading, $(0.05 \mathrm{~g})$, however, not significantly different from the level 50\% (0.08 g). A. macrocarpa showed statistical difference, for RDM $0.09(\mathrm{~g})$ in full sun, and low development $0.04(\mathrm{~g})$ at $80 \%$ shading. 
DEVELOPMENT OF Tabebuia aurea AND Anadenanthera macrocarpa UNDER DIFFERENT LEVELS...

Table 2. Means of the dry mass of the aerial part (APDM), roots (RDM) and APDM/RDM rate

\begin{tabular}{ccccccc}
\hline & \multicolumn{5}{c}{ SPECIES } \\
\cline { 2 - 6 } & \multicolumn{5}{c}{ A. macrocarpa } & T. aurea \\
\cline { 2 - 6 } SHADING & APDM (g) & RDM (g) & APDM/RDM & APDM (g) & RDM (g) & APDM/RDM \\
\hline $\begin{array}{c}\text { Full sun (absence } \\
\text { of shade) }\end{array}$ & $0.06 \mathrm{a}$ & $0.09 \mathrm{a}$ & $0.64 \mathrm{c}$ & $0.16 \mathrm{a}$ & $0.15 \mathrm{a}$ & $1.11 \mathrm{a}$ \\
\hline $50 \%$ & $0.06 \mathrm{a}$ & $0.07 \mathrm{~b}$ & $0.84 \mathrm{~b}$ & $0.13 \mathrm{a}$ & $0.08 \mathrm{~b}$ & $3.08 \mathrm{a}$ \\
\hline $80 \%$ & $0.05 \mathrm{a}$ & $0.04 \mathrm{c}$ & $1.15 \mathrm{a}$ & $0.14 \mathrm{a}$ & $0.05 \mathrm{~b}$ & $2.91 \mathrm{a}$ \\
\hline
\end{tabular}

* The means were analyzed for each species by the test of Tukey at $5 \%$ probability.

The greater development (RDM) of T. aurea in full sun may be linked to a high photosynthetic activity, generating an increase in carbon fixation and consequently a greater weight of dry matter. For A. macrocarpa, there was no statistical difference for APDM between the three levels of shading, whereas for RDM, this difference occurred with the level of full sun showing the greatest development in the species.

Marana et al. (2015) showed that as light intensity decreases, the production of dry mass is reduced as because carbohydrate uptake is higher in the respiration than produced by photosynthesis. Responses related to changes in light availability can occur in some part of the plant, resulting in a change in its growth (OLIVEIRA; GUALTIERI, 2011).

This result was also found by Oliveira and Perez (2012a), when they observed that Tabebuia aurea obtained the highest dry mass values in the treatments with the highest light intensity.

The reduction of the dry mass of the aerial part and the root occurs as a consequence in the alterations in the water relations of the plant cell (SILVA et al., 2019). Similar behavior was observed by Fanti and Perez (2003), when studying Adenanthera pavonina $L$. seedlings.

Regarding the Dickson index (Table 3), the development of seedlings was positively influenced by the high luminosity. Thus, all indexes promote the production of both species without the use of shading.

The species A. macrocarpa had an DQI at full sun of 0.03454 , which was the highest value found for this species among the different levels of shading. The species T. aurea obtained an DQI of 0.11719, in full sun, the highest index found.

Oliveira et al. (2012b), when analyzing the development of $T$. Aurea at different levels of shading, obtained higher average values for cultivation in full sun, indicating that the growth of this culture may have better results under these conditions.

The Dickson quality index is a good indicator of seedling quality, as it considers the vigor and balance of the biomass distribution in the seedling. The index weighs the results of many variables. The morphological variables and the indices used to evaluate the quality of seedlings can be used alone or together, to classify the quality standard of seedlings, provided that they are used in seedlings developed under similar environmental conditions (FONSECA et al., 2002).

Studies on the adaptation of tree species to the different light availability in their growing environment is important, in order to contribute to the development of planting techniques and management of seedlings of these species, in the

Table 3. Dickson Quality Index (DQI) ratio in different shading levels

\begin{tabular}{ccc}
\hline SHADING & \multicolumn{2}{c}{ SPECIES } \\
\cline { 2 - 3 } & A. macrocarpa & T. aurea \\
\hline Full sun (absence of shade) & $0.03454 \mathrm{a}$ & $0.11719 \mathrm{a}$ \\
\hline $50 \%$ & $0.02023 \mathrm{~b}$ & $0.04170 \mathrm{~b}$ \\
\hline $80 \%$ & $0.01144 \mathrm{c}$ & $0.02632 \mathrm{~b}$ \\
\hline
\end{tabular}

\footnotetext{
* The means were analyzed for each species by the test of Tukey at $5 \%$ probability.
} 
perspective of multiple uses of the forest, such as reforestation and commercial plantations aiming at minimizing the mortality rate of these species in the field (LIMA et al., 2010).

When comparing the results, we observed that both species adapted to full sun, but $T$. Aurea has a greater prominence, with full sun being the most suitable shade level for planting.

\section{CONCLUSIONS}

- The species T. Aurea showed little tolerance when subjected to high levels of shading, indicating that the luminosity interferes with the initial growth of the species. $A$. macrocarpa, also obtained better development in full sun, showing less progress at higher levels of shading.

- The highest values of the Dickson Quality Index (DQI) were observed in seedlings grown under a lower level of shading.

- For the initial production of seedlings of both species, no artificial shading is required

\section{REFERENCES}

CABRAL, E.L.; BARBOSA, D.C.A.; SIMABUKURO, E.A. Armazenamento e germinação de sementes de Tabebuia aurea (Manso) Benth. e HooK. F. EX. S. Moore. Acta Botanica Brasilica, São Paulo, v.17, n.4, p.30-43, 2003.

CALDEIRA, M.V.W.; ROSA, G.N..; FENILLI, T.A.B.; HARBS, R.M.P. Composto orgânico na produção de mudas de Aroeira-vermelha. Scientia Agraria, Curitiba, v.9, n.1, p.27-33, 2008.

COSTA, M.E.; MIRANDA, N.O.; PIMENTA, A.S.; NASCIMENTO, E.K.A.; RODRIGUES, A.P.M.S.; JÚNIOR, A.F. M. Massa seca e teores de nutrientes de plantas de milho sob efeito de águas salinas e biochar. Revista Verde, Pombal, v.13, n.4, p.672-682, 2018.

CÂMARA, C.A.; ENDRES, L. Desenvolvimento de mudas de duas espécies arbóreas: Mimosa caesalpiniifolia Benth. e Sterculia foetida sob diferentes níveis de sombreamento em viveiro. Revista Floresta, Curitiba, v.38, n.1, p.43-51, 2008.

CAMPOS, M.A.A.; UCHIDA, T. Influência do sombreamento no crescimento de mudas de três espécies amazônicas. Pesquisa Agropecuária Brasileira, Brasília, v.37, n.5, p.281-288, 2002.

CHAVES,L.L.B.; CARNEIRO, J.G.A.;BARROSO, D.G. Crescimento de mudas de Anadenanthera macrocarpa (Benth) Brenan (Angico-Vermelho) em substrato fertilizado e inoculado com rizóbio. Revista Árvore, Viçosa, v.30, n.6, p.911-919, 2006.

DICKSON, A.; LEAF, A.L.; HOSNER, J.F. Quality appraisal of white spruce and white pine seedling stock in nurseries. The Forestry Chronicle. Canada, v.36, n.2, p.10-13, 1960.

ELOY, E.; CARON, B.O.; SCHMIDT, D.; BEHLING, A.; SCHWERS, L.; ELLI, E.F. Avaliação da qualidade de mudas de Eucalyptus grandis utilizando parâmetros morfológicos. Revista Floresta, Curitiba, v.43, n.3, p.373-384, 2013.

FANTI, S.C.; PEREZ, S.C.J.G. A Influência do sombreamento artificial e da adubação química na produção de mudas de Adenanthera pavonina L. Ciência Florestal, Santa Maria, v.13, n.4, p.49-56, 2003.

FONSECA, E.P.; VALÉRI, S.V.; MIGLIORANZA, E.; FONSECA, N.A.N.; COUTO, L. Padrão de qualidade de mudas de Trema micranta (L.) Blume, produzidas sob diferentes períodos de sombreamento. Revista Árvore, Viçosa, v.26, n.4, p.515-523, 2002.

GOMES, D.R.; CALDEIRA, M.V.W.; DELARMELINA, W.M.; GONÇALVES, E.O.; TRAZZI, P.A. Lodo de esgoto como substrato para a produção de mudas de Tectona grandis L. Cerne, v.19, n.1, p.123-131, 2013.

LARCHER, W. Ecofisiologia Vegetal: 3. ed. São Paulo: Editora Rima, 2004. 
DEVELOPMENT OF Tabebuia aurea AND Anadenanthera macrocarpa UNDER DIFFERENT LEVELS...

LIMA, M.A.O.; MIELKE, M.S.; LAVINSKY, A.O.; FRANÇA, S.; ALMEIDA, A.A.F.; GOMES, F.P. Crescimento e plasticidade fenotípica de três espécies arbóreas com uso potencial em sistemas agroflorestais. Scientia Forestalis, v.38, n.87, p.527-534, 2010.

LIMA, J.D.; SILVA, B.M.S.; MORAES, W.S.; DANTAS, V.A.V.; ALMEIDA, C.C. Efeitos da luminosidade no crescimento de mudas de Caesalpinia ferrea Mart. ExTul. (Leguminosae, Caesalpinoideae). Acta Amazonica, v.38, n.1, p.510, 2008.

MARANA, J.P.; MIGLIORANZA, E.; FONSECA, E.P. Qualidade de mudas de jaracatiá submetidas a diferentes períodos de sombreamento. Revista Árvore, Viçosa, v.39, n.2, p.275-282, 2015.

NÓBREGA, R.S.A.; BOAS, R.C.V.; NÓBREGA, J.C.A.; PAULA, A.D.; MOREIRA, F.D.S. Utilização de biossólido no crescimento inicial de mudas de aroeira (Schinus terebynthifolius Raddi). Revista Árvore, Viçosa, v.31, n.2, p.239-246, 2007.

OLIVEIRA， A.K.M.; PEREZ， S.C.J.G.A. Crescimento inicial de Tabebuia aurea sob três intensidades luminosas. Ciência Florestal, Santa Maria, v.22, n.2, p.263-273, 2012.

OLIVEIRA, A.K.M.; LAURA, V.A.; PEREZ, S.C.J.G.A. A influência da luminosidade no desenvolvimento vegetal. Uniderp, v.7, n.8, p.97118, 2012.

OLIVEIRA, A.K.M.; GUALTIERI, S.C.J. Crescimento inicial de Tabebuia aurea sob três intensidades luminosas. REVSBAU, Piracicaba, v.6, n.2, p.90-103, 2011.

ROSA, L.; VIEIRA, T.A.; SANTOS, D.S.; SILVA, L.C.B. da. Emergência, crescimento e padrão de qualidade de mudas de Schizolobium amazonicum Huber ex Ducke sob diferentes níveis de sombreamento e profundidades de semeadura. Revista ciência agrária, Belém, v.4, n.32, p.8798, 2009.

SARAIVA, G.F.R.; SOUZA, G.M.; RODRIGUES, J.D. Aclimatação e fisiologia de mudas de guanandi cultivadas em telas de sombreamento foto-protetoras. Colloquium Agrariae, Presidente Prudente, v.10, n.2, p.1-10, 2014.

SILVA, E.C.A.; COSTA, J.R.S.; COSTA, P.C.F.; ALCANTARA, A.M.A.; SANTOS, C.A.; NOGUIERA, R.J.M.C. Salinidade na emergência e no crescimento inicial de mulungu. Ciência Agrícola, Rio Largo, v.17, n.1, p.63-69, 2019.

SOUSA, A.S.; JARDIM, M.A.G. Sobrevivência e mortalidade de plântulas de açaizeiro (Euterpe oleracea Mart.) cultivadas em capoeira no nordeste paraense. Revista Brasileira de Biociência, Porto Alegre, v.5, n.1, p.255-257, 2007.

VIEIRA, C.R.; WEBER, O.L.S.; SCARAMUZZA, J.F. Influência do vermicomposto no crescimento e na nutrição de mudas de angico cascudo. Revista Biociência, Taubaté, v.20, n.2, p.52-61, 2014.

WANGINIAK, Thayna Cristiane Rebello. Desenvolvimento inicial de guanandi (Calophllum brasiliense cambess, Clusiaceae) em sistema sob cobertura e pleno sol. 2016. 42f. Dissertação (mestrado) - faculdade de ciências agronômicas da UNESP, Botucatu, 2016. 